\title{
Early Evaluation of Compatibility between Commercial Citrus Varieties and Kaffir Lime (Citrus hystrix) and Carrizo Citrange (C. sinensis Osb. x P. trifoliata L. Raf.) Rootstocks at Mekong Delta, Vietnam
}

\author{
Le Thi Khoe ${ }^{\#}$, Tran Van Mi ${ }^{*}$ \\ \# Division of Pomology, Southern Horticultural Research Institute (SOFRI) Vietnam. P.O. Box 203 My Tho-Tien Giang-Vietnam. \\ E-mail:ltkhoe@yahoo.com.vn
}

*Division of Agriculture and Rural Development Tri Ton, An Giang, Vietnam

\begin{abstract}
The results of investigation on early evaluation of compatibility between commercial citrus varieties, and Kaffir lime (Citrus hystrix) and Carrizo citrange $(C$. sinensis Osb. $x$ P. trifoliata L. Raf.) rootstocks, at Mekong Delta Vietnam, during four successive years from 2010 to 2013, reported that out of the tested combinations of the recent commercial citrus varieties, included Da xanh pumelo $(C$. grandis Osbeck), seedless Mat orange $(C$. sinensis L. Osbeck), Sanh orange $(C$. nobilis Lour.) and Duong mandarin ( $C$. reticulata), budded on Kaffir lime and Carrizo citrange, in the $3^{\text {rd }}$ and $4^{\text {th }}$ year after planting under the trial fields at Mekong Delta Vietnam, the trees of Sanh orange (C. nobilis Lour.) budded on Kaffir lime (Citrus hystrix) were supperior with precocity, producing high number of fruits $(16.67$ fruits per tree $)$, and very good fruit quality of larger fruit size $(334.6 \mathrm{~g}$ and $11.16 \mathrm{~cm}$, fruit weight and diameter, respectively), higher total soluble solids (12.5 brix), better orange-yellow juice color development, and excellent flavor and aroma of juice, as compared to the typical characteristics; meanwhile these were followed by trees of seedless Mat orange budded on Kaffir lime, which produced the highest number of fruits (47.33 fruits per tree), with little inferior quality of seedy fruit (13 seeds per fruit), lower total soluble solids $(\mathbf{7 . 3 3 \%})$, and no good flavor and aroma, as somewhat differed from the typical fruit traits.
\end{abstract}

Keywords — Citrus spp., grafted, Kaffir lime, Mekong Delta, rootstock, Vietnam.

\section{INTRODUCTION}

Investigations of citrus scion and rootstock combinations have clearly revealed that the rootstocks impart to the tolerance or resistance to pest, disease, and the adverse environmental conditions as cool, drought, saline the growth and development, yield and fruit quality of the grafted trees [4]; and today, under climate changing, the watering source might be scarce and limit; so studying and using the drought resistant rootstocks of fruit crops may be required; moreover, there are around 29,320 hectares of the natural area of foot hills, with 300 to $710 \mathrm{~m}$ hight above sea level, at Tri Ton and Tinh Bien district of An Giang province, Mekong Delta region, Vietnam; where the local farmers have always encountered with many difficulties in agricultural production, because of the extreme limiting of water resource for irrigation in dry season. So, the selection of the citrus graft trees for drought tolerance in cultivation is the important helping for the effective land using and sustainable agricultural production in this region; so that it may contribute to increase famers' income. Therefore, the results of the long term researches consisted of the primary evaluation and selection of the local citrus genotypes, being wild and cultivated, for drought tolerance under the natural conditions at Vietnam southern region; and screening for drought tolerance, under the combined artificial (in greenhouse) and natural (in trial field) drought stressor demonstrated that out of 28 local citrus genotypes plus 2 hybrids, Kaffir lime (Citrus hystrix); which had been mountainous wild plant in South Vietnam; while used as leafy spice in Asia nations such as Thailand, Indonesia, Malaysia; Chua pumelo (C. grandis Osbeck), Thanh tra pumelo ( $C$. grandis Osbeck), Do pummelo (C. grandis Osbeck) had been selected as better drought tolerance based on some physiological responses of chlorophyll fluorescence, visual wilting symtoms, biochemical traits consisted of total chlorophyll, proline, soluble sugar and starch contents, and morphological traits [2, 3]. Extensively, a investigation on early evaluation of compatibility between commercial citrus varieties and Kaffir lime (Citrus hystrix) and Carrizo 
citrange (C. sinensis Osb. x P. trifoliata L. Raf.) rootstocks in greenhouse and under trial field at Mekong Delta, Vietnam in duration of 2010-2013 was conducted to determine the good scion and stock combination for drought tolerance and good production with high fruit quality to introduce to citrus growers at the region with limiting irigration water source.

\section{MATERIALS AND METHODS}

\section{A. Experimental Layout}

The recent commercial varieties of citrus consisted of Da xanh pumelo ( $C$. grandis Osbeck), seedless Mat orange ( $C$. sinensis L. Osbeck), Sanh orange (C. nobilis Lour.) and Duong mandarin (C. reticulata) were budded on rootstocks of Kaffir lime (Citrus hytrix) and Carrizo citrange (C.sinensis Osb.xP. trifoliata L. Raf.) propagated with cutting method. The experiment was established in early September 2010, in split plot design with three replications and single graft tree with 6 months after budding, per replication. Trees were planted at five and six meter planting distance in plants and rows, at foot-hill area with 440 meters above sea level, around 8 degree slope, located at Nui Dai area belong to Tri Ton district, An Giang province in Mekong Delta, Vietnam. The soil characteristics of trial field was $6.03 \mathrm{pH}$ in 1:2.5 soil: water suspension, 0.06 $\mathrm{mS} / \mathrm{cm}$ electric conductivity in the saturation extract, 0.99 percent organic content.

TABLE I

SOIL CHARACTERISTICS AT TRIAL SITE

\begin{tabular}{|l|l|}
\hline $\mathrm{pH}$ & 6.03 \\
\hline Electric conductivity $(\mathrm{mS} / \mathrm{cm})$ & 0.06 \\
\hline Organic matter $(\%)$ & 0.99 \\
\hline Sand $(\%)$ & 86.50 \\
\hline Silt $(\%)$ & 11.40 \\
\hline Clay $(\%)$ & 2.11 \\
\hline
\end{tabular}

The climate conditions in dry seasons at experimental site from 2010 to 2012 were presented as below:

\section{TABLE II}

TEMPERATURE, PRECIPITATION, EVAPORATE AND SUNSHINE HOURS AT TRIAL SITE IN 2010-2011

\begin{tabular}{|l|c|c|c|}
\hline & Temperature $\left({ }^{\circ} \mathrm{C}\right)$ & $\begin{array}{c}\text { Precipitation } \\
(\mathrm{mm} / \mathrm{month})\end{array}$ & $\begin{array}{c}\text { Evaporate } \\
(\mathrm{mm})\end{array}$ \\
\hline Nov, 2010 & 26,7 & 408,0 & 83,6 \\
\hline Dec, 2010 & 26,3 & 23,2 & 103,5 \\
\hline Jan, 2011 & 25,7 & - & 122,7 \\
\hline Feb, 2011 & 26,0 & 1,6 & 89,9 \\
\hline Mar, 2011 & 27,4 & 115,8 & 129,0 \\
\hline Apr, 2011 & 28,2 & 30,3 & 120,8 \\
\hline May, 2011 & 28,7 & 109,7 & 108,1 \\
\hline
\end{tabular}

The trees were irrigated weekly from December to March using basal irrigation method. In the first year after planting, the trees were fertilized with Urea and Di-ammonium Phosphate; and later on applied with NPK-20-20-15 fertilizer. Disease and pest populations were controlled according to integrated pest management (IPM) method.
TABLE III

TEMPERATURE, PRECIPITATION, EVAPORATE AT TRIAL SITE IN 2011-2012

\begin{tabular}{|c|c|c|c|}
\hline & Temperature $\left({ }^{\mathrm{o}} \mathrm{C}\right)$ & $\begin{array}{c}\text { Precipitation } \\
(\mathrm{mm} / \mathrm{month})\end{array}$ & $\begin{array}{c}\text { Evaporate } \\
(\mathrm{mm})\end{array}$ \\
\hline Nov, 2011 & 27,8 & 179,1 & 77,8 \\
\hline Dec, 2011 & 26,0 & 40,6 & 103,1 \\
\hline Jan, 2012 & 26,6 & 0,2 & 84,5 \\
\hline Feb, 2012 & 26,8 & 1,4 & 81,0 \\
\hline Mar, 2012 & 28,1 & 51,2 & 102,8 \\
\hline Apr, 2012 & 28,7 & 97,2 & 100,8 \\
\hline May, 2012 & 28,5 & 155,5 & 89,5 \\
\hline
\end{tabular}

\section{B. Recordings of Vegetative Traits}

In december, 2013, as four years after planting, tree height, and canopy height and canopy diameter in the two directions were measured. Then, the canopy volume (CV) was calculated from canopy height and spread, by using the formula suggested by Westwood (1993): $C V=4 / 3 \pi a b^{2}$, where $a$ is the major axis length $/ 2$, and $b$ is the minor axis length/2 [6]. In addition, stock and scion trunk diameters were measured $5 \mathrm{~cm}$ below and above the bud union by digital caliper, and scion/stock ratio was calculated as described by Legua et al. (2011) [7].

\section{Recordings of Fruit Yield and Quality}

Fruit yield of each tree was annually determined during harvesting in season of 2012 and 2013, when fruits were harvested, counted and weighed at harvest time, from the end of January to early April, and 3 to 10 random fruits per tree were sampled to weight and to measure diameter; then the rind thickness was undertaken with helps of digital caliper, after cutting fruit in haft, for seed number trait, seeds of fruit were counted, total soluble solids (TSS) content of fruit juice was determined with a refractormeter (Atago, Japan), using few drops of juice and the fruit flavor and aroma were evaluated using sensorial and visual acceptibility as compared to the typical characteristics.

\section{Data Analysis}

The data recorded were subjected to ANOVA analyse using MSTAT-C program and mean comparations were done with least signficant difference (LSD) at five percent level of probability.

\section{RESULTS AND DISCUSSION}

\section{A. Vegetative Parameters}

There were differences in the vegetative parameters among scions, rootstocks and the scion and rootstock combinations in the fourth year after planting, as data presented in Table 4.

Mean tree height, canopy volume, trunk diameter and ratio of scion and stock of Kaffir lime rootstock were better than that of Carrizo citrange; meanwhile, the tallest tree of $283.83 \mathrm{~cm}$ value was producted by Sanh orange scion and lager canopy volume of $8.44 \mathrm{~m}^{3}$ value and trunk diameter of $72.45 \mathrm{~mm}$ were recorded on Da xanh pumelo scion. 
TABLE IV

Tree Height, CANopy Volume, Trunk Diameter AND Scion AND STOCK Ratio

\begin{tabular}{|c|c|c|c|c|}
\hline Scion/ rootstock & $\begin{array}{l}\text { Tree height } \\
(\mathrm{cm})\end{array}$ & $\begin{array}{c}\text { Canopy volume } \\
\left(\mathrm{m}^{3}\right)\end{array}$ & $\begin{array}{l}\text { Trunk diameter } \\
(\mathrm{mm})\end{array}$ & Scion/stock ratio \\
\hline \multirow{8}{*}{$\begin{array}{l}\text { Seedless Mat orange/Kaffir lime } \\
\text { Sanh orange/Kaffir lime } \\
\text { Da xanh pumelo/Kaffir lime } \\
\text { Duong mandarin/Kaffir lime } \\
\text { Seedless Mat orange/Carrizo citrange } \\
\text { Sanh orange/Carrizo citrange } \\
\text { Da xanh pumelo/Carrizo citrange } \\
\text { Duong mandarin/Carrizo citrange }\end{array}$} & 220.00 & $8.02(2.51)$ & 62.63 & $1.00(1.00)$ \\
\hline & 285.33 & $6.20(2.45)$ & 74.27 & $0.99(1.00)$ \\
\hline & 263.33 & $10.11(3.07)$ & 74.30 & $1.00(1.00)$ \\
\hline & 143.33 & $0.53(0.67)$ & 34.17 & $1.03(1.01)$ \\
\hline & 105.00 & $0.66(0.81)$ & 45.03 & $0.96(0.98)$ \\
\hline & 282.33 & $1.60(1.26)$ & 57.20 & $0.94(0.97)$ \\
\hline & 206.67 & $6.76(2.42)$ & 70.60 & $1.05(1.02)$ \\
\hline & 166.67 & $1.94(1.29)$ & 44.20 & $1.02(1.01)$ \\
\hline $\operatorname{LSD}(5 \%)$ & 24.56 & 0.82 & 14.52 & 0.02 \\
\hline \multirow{4}{*}{$\begin{array}{l}\text { Seedless Mat orange } \\
\text { Sanh orange } \\
\text { Da xanh pumelo } \\
\text { Duong mandarin }\end{array}$} & 162.50 & $4.34(1.66)$ & 53.83 & $0.98(0.99)$ \\
\hline & 283.83 & $3.90(1.86)$ & 65.73 & $0.97(0.98)$ \\
\hline & 235.00 & $8.44(2.74)$ & 72.45 & $1.03(1.01)$ \\
\hline & 155.00 & $1.24(0.98)$ & 39.18 & $1.03(1.01)$ \\
\hline \multirow{2}{*}{$\begin{array}{l}\operatorname{LSD}(5 \%) \\
\mathrm{CV}(\%)\end{array}$} & 22.14 & 0.71 & 12.05 & 0.01 \\
\hline & 13.30 & 49.44 & 26.18 & 1.71 \\
\hline \multirow{2}{*}{$\begin{array}{l}\text { Kaffir lime } \\
\text { Carrizo citrange }\end{array}$} & 228.00 & $6.21(2.17)$ & 60.42 & $1.00(1.00)$ \\
\hline & 190.17 & $2.74(1.45)$ & 55.18 & $0.99(1.00)$ \\
\hline \multirow{2}{*}{$\begin{array}{l}\operatorname{LSD}(5 \%) \\
\mathrm{CV}(\%)\end{array}$} & 19.02 & 0.79 & 15.81 & 0.02 \\
\hline & 4.73 & 22.65 & 14.22 & 1.00 \\
\hline
\end{tabular}

Note: Values in the parentheses were transformed to square root

TABLE V

QuALITy OF Fruit From SANH ORANGE Budded On KAFFIR Lime AND SPECIFIC Characteristics OF SANH ORANGE

\begin{tabular}{|l|l|l|l|l|}
\hline \multirow{2}{*}{ Traits } & \multicolumn{2}{c|}{ Sanh orange/Kaffir lime } & Specific characteristics ${ }^{*}$ ) \\
\cline { 2 - 5 } & \multicolumn{1}{|c|}{$\mathbf{2 0 1 2}$} & \multicolumn{1}{c|}{$\mathbf{2 0 1 3}$} & \multicolumn{1}{c|}{ Mean } & \\
\hline Yield (kg/tree) & $4,95 \pm 1,91$ & $5,53 \pm 0,52$ & 5,24 & - \\
\hline Fruit weight (gr) & $300 \pm 41$ & $334,6 \pm 17,61$ & 317 & 270 \\
\hline Brix of fruit juice (\%) & $8 \pm 0,41$ & 12,5 & 10,25 & 8,3 \\
\hline Seeds & $9,33 \pm 1,15$ & $15 \pm 7$ & 12,17 & 11,8 \\
\hline Fruit diameter (cm) & $8,5 \pm 0,63$ & $11,16 \pm 0,81$ & 9,83 & 8,5 \\
\hline Rind thickness (mm) & $4,5 \pm 0,56$ & $4,45 \pm 0,54$ & 4,48 & 4,48 \\
\hline Fruit juice percentage (\%) & $41 \pm 0,8$ & $41,48 \pm 0,47$ & 41,24 & 37,2 \\
\hline Fruit juice flavor & Mild acid- sweet & Sour-sweet & & Sour-sweet \\
\hline Fruit shape & Sphere & Suppress-sphere & & Suppress-sphere \\
\hline Juice color & Orange-yellow & & Orange color \\
\hline
\end{tabular}

Note: ${ }^{(*)}$ Sources from Southern Horticultural Research Institute, 2009

TABLE VI

FRUIT YIELDED, FRUIT WEIGHT AND DiAMETER IN 2013

\begin{tabular}{|l|l|l|l|}
\hline Scion/ rootstock & Fruits/tree & Fruit weight (g) & Fruit diameter (cm) \\
\hline Seedless Mat orange/Kaffir lime & 47.33 & 200.00 & 8.10 \\
\hline Sanh orange/Kaffir lime & 16.67 & 334.60 & 11.16 \\
\hline Da xanh pumelo/Kaffir lime & 6.67 & 1.260 .00 & 15.75 \\
\hline Duong mandarin/Kaffir lime & 8.33 & 123.33 & 6.47 \\
\hline Seedless Mat orange /Carrizo citrange & 5.33 & 201.67 & 8.03 \\
\hline Sanh orange /Carrizo citrange & 5.33 & 303.33 & 9.4 \\
\hline Da xanh pumelo /Carrizo citrange & 4.00 & 1.186 .67 & 14.83 \\
\hline Duong mandarin /Carrizo citrange & 6.33 & 126.67 & 6.57 \\
\hline LSD (5\%) & 2.76 & 20.60 & 0.60 \\
\hline Seedless Mat orange & 26.33 & 200.83 & 8.07 \\
\hline Sanh orange & 11.00 & 318.97 & 10.28 \\
\hline Da xanh pumelo & 5.33 & 1.223 .33 & 15.29 \\
\hline Duong mandarin & 7.33 & 125.00 & 6.52 \\
\hline CV $\%)$ & 11.12 & 4.62 & 5.17 \\
\hline LSD (5\%) & 1.11 & 17.17 & 0.41 \\
\hline Kaffir lime & 19.75 & 479.48 & 10.37 \\
\hline Carrizo citrange & 5.25 & 454.58 & 9.71 \\
\hline CV (\%) & 19.8 & 2.47 & 4.55 \\
\hline LSD (5\%) & 4.76 & 0.88 \\
\hline
\end{tabular}


As considered to graft trees, results showed that tree height of Sanh orange budded on Kaffir lime was $285.33 \mathrm{~cm}$, followed by $263.33 \mathrm{~cm}$ of Da xanh pumelo budded on Kaffir lime, and these were significantly taller than that from seedless Mat orange budded on Kaffir lime with $220.0 \mathrm{~cm}$ height and Duong mandarin on Kaffir lime being $143.33 \mathrm{~cm}$ high. Moreover, the canopy volume of Da xanh pummelo budded on Kaffir lime of $10.11 \mathrm{~m}^{3}$ was followed by that of seedless Mat orange on Kaffir lime with $8.02 \mathrm{~m}^{3}$ volume and Sanh orange on Kaffir lime with $6.20 \mathrm{~m}^{3}$ volume; but no significant difference was found among these combinations; meanwhile, the smallest canopy volume was found on Duong mandarin budded on Kaffir lime with $0.53 \mathrm{~m}^{3}$ volume.

In addition, data revealed clearly that tree of seedless Mat orange on Kaffir lime produced $105.0 \mathrm{~cm}$ tree height were dwarfish; meanwhile, its large canopy volume was not significant different from combinations of Sanh orange and Da xanh pumelo budded on Kaffir lime.

With regarding to trunk growth of budded trees, the results showed that larger trunk diameter of $62.63 \mathrm{~mm}$ value was obtained from the trees of seedless Mat orange budded on Kaffir lime, and followed by that from Da xanh pumelo budded on Kaffir lime with 74.30mm value and Sanh orange budded on Kaffir lime of $74.27 \mathrm{~mm}$ trunk diameter; however, the least trunk diameter of $34.17 \mathrm{~mm}$ value was obtained from trees of Duong mandarin budded on Kaffir lime.

Althought, significant difference in scion and stock ratios among combinations of seedless Mat orange 1.00, Sanh orange 0.99 , Da xanh pumelo 1.0 and Duong mandarin 1.03 budded on Kaffir lime was not found.

These results having obtained from the tested combinations of scion and Kaffir lime and Carrizo citrange were agreement with findings of Ercan et al. (2013), who found that rootstock affected tree growth and development of orange cultivars of Rhode Red, Valencia, Valencia Late, and mandarin [9]. In addition, Bassal (2009) also reported that Carrizo citrange rootstock did not induced the better growth of Marisol mandarin trees as compared to Sour orange rootstock [5]. On other hand, in Vietnam condition, the earlier research on grafted trees of citrus conducted at Gia Lam, Ha noi, Pham Thi Huong (2006) proved that methods of propagation of the tested rootstocks imparted into the vegetative parameters of Duong canh mandarin scion [8].

\section{B. Fruit Yield and Quality}

In the third year after planting of 2012, the most outstanding of experimental combinations was demonstrated primarily that trees of Sanh orange budded on Kaffir lime producted precociously good quality fruits with $300 \mathrm{~g}$ weight, high total soluble solids of 41.0 brix, $4.5 \mathrm{~mm}$ rind thickness, better color development, and better flavor and aroma of fruit juice as compared to the specific fruit attributes; as presented in table 5 .

Subsequently, in fourth year of 2013, after planting, all combinations of scion and rootstock producted firstly fruits, except trees of Sanh orange budded on Kaffir lime which were the second season of harvesting. And data tabulated in table 6 clearly showed that trees budded on Kaffir lime were higher number of 19.75 fruits than that on Carrizo citrange with 5.25 fruit number. Simmilarly, fruit quality consisted of fruit size, total soluble solid, number of seeds and rind thickness was better from budded on Kaffir lime.

These investigation also demonstrated that the highest fruit number harvested was 47.33 fruits per tree from trees of seedless Mat orange budded on Kaffir lime, and followed by 16.67 fruits from trees of Sanh orange budded on Kaffir lime, 8.33 fruits from Duong mandarin, and 6.67 fruits from Da xanh pumelo budded on Kaffir lime.

The fruit weights and diameters, respectively were $1.260 \mathrm{~g}$ and $15.75 \mathrm{~cm}$ from trees of Da xanh pumelo, $334.6 \mathrm{~g}$ and $11.16 \mathrm{~cm}$ from Sanh orange, $200 \mathrm{~g}$ and $8.1 \mathrm{~cm}$ from seedless Mat orange, whereas lowest fruit size of $123.33 \mathrm{~g}$ and $6.47 \mathrm{~cm}$ from Duong mandarin budded on Kaffir lime.

In addition, total soluble solid content of fruit juice were 12.5 brix observed from fruits of Sanh orange trees budded on Kaffir lime, and followed by 9.23 brix from Da xanh pumelo budded on Kaffir lime; meanwhile, 8.33 brix of soluble solid content of fruit juice was of fruits from trees of Duong mandarin budded on Kaffir lime; finally, the lowest total soluble solids was 7.33 brix of the fruits from seedless Mat orange budded on Kaffir lime.

Moreover, data obtained in table 4 also showed that the seed number of fruit was 15.0 seeds from Sanh orange budded on Kaffir lime, and 9.0 seeds from Da xanh pumelo budded on Kaffir lime; finally 8.33 seeds per fruit were recorded on Duong mandarin budded on Kaffir lime; however, seedless Mat orange was found as natural mutation genotype under commercial production field, in this investigation fruits from seedless Mat orange grafted on Kaffir lime were occasional 0 to 3 seeds.

With regarding to the fruit rind thickness, that ranged $16.33 \mathrm{~mm}, 4.45 \mathrm{~mm}, 3.1 \mathrm{~mm}$ and $1.47 \mathrm{~mm}$ were found from Da xanh pumelo, Sanh orange, seedless Mat orange and Duong mandarin budded on Kaffir lime, respectively. Therefore, these significant differences were mostly contributed by specific characteristics of citrus species budded on Kaffir lime.

Meanwhile, the tested combinations budded on Carrizzo citrange rootstock producted from 4.0 to 6.33 fruits per tree, and significant difference was found among these combinations. In considering to fruit quality, fruit weight and diameter were $1.186 .67 \mathrm{~g}$ and $14.83 \mathrm{~cm}$, respectively, of fruits from trees of Da xanh pumelo on Carrizo citrange, $303.33 \mathrm{~g}$ and $9.4 \mathrm{~cm}$ of Sanh orange on Carrizo citrange, $201.67 \mathrm{~g}$ and $8.03 \mathrm{~cm}$ of seedless Mat orange on Carrizo citrange, and $126.67 \mathrm{~g}$ and $6.57 \mathrm{~cm}$ of Duong mandarin budded on Carrizo citrange.

Similarly, total soluble solid content of fruit juice from combinations on Carrizo citrange ranged from 7.23 to 10.67 of brix; and seed number of fruit also varied from 9.67 to 14.33 seeds per fruit; excepted to trees of seedless Mat orange budded on Carrizo citrange rootstock that maintained the seedless fruit of specific characteristics. 
TABLE VII

Total Soluble Solids (Brix, \%) OF Fruit Juice, Number Of SEEDS AND Rind ThickNESS

\begin{tabular}{|l|l|l|l|}
\hline Scion/ rootstock & Brix $(\%)$ & Seed number & Rind thickness (mm) \\
\hline Seedless Mat orange/Kaffir lime & 7.33 & $0.67(1.00)$ & 3.10 \\
\hline Sanh orange/Kaffir lime & 12.50 & $15.00(3.87)$ & 4.45 \\
\hline Da xanh pumelo/Kaffir lime & 9.23 & $9.00(2.82)$ & 16.33 \\
\hline Duong mandarin/Kaffir lime & 8.33 & $8.33(2.97)$ & 1.47 \\
\hline Seedless Mat orange /Carrizo citrange & 7.23 & $0(0.71)$ & 3.50 \\
\hline Sanh orange/Carrizo citrange & 10.67 & $14.33(3.81)$ & 4.60 \\
\hline Da xanh pumelo /Carrizo citrange & 9.00 & $12.00(3.41)$ & 18.33 \\
\hline Duong mandarin /Carrizo citrange & 7.87 & $9.67(3.17)$ & 1.43 \\
\hline LSD (5\%) & 0.96 & 0.89 & 1.01 \\
\hline Seedless Mat orange & 7.23 & $0.33(0.86)$ & 3.30 \\
\hline Sanh orange & 11.58 & $14.67(3.84)$ & 4.53 \\
\hline Da xanh pumelo & 9.12 & $10.50(3.12)$ & 17.33 \\
\hline Duong mandarin & 8.1 & $9.00(3.07)$ & 1.45 \\
\hline CV $(\%)$ & 5.72 & 31.04 & 8.76 \\
\hline LSD $(5 \%)$ & 0.41 & 0.67 & 0.46 \\
\hline Kaffir lime & 9.35 & $8.25(2.66)$ & 6.34 \\
\hline Carrizo citrange & 8.69 & $9.00(2.78)$ & 6.97 \\
\hline CV $(\%)$ & 9.48 & 21.97 & 13.39 \\
\hline LSD (5\%) & 1.65 & 1.15 & 1.71 \\
\hline
\end{tabular}

Noted: Values in parentheses were transformed in square-root $(\mathrm{x}+0.5)$

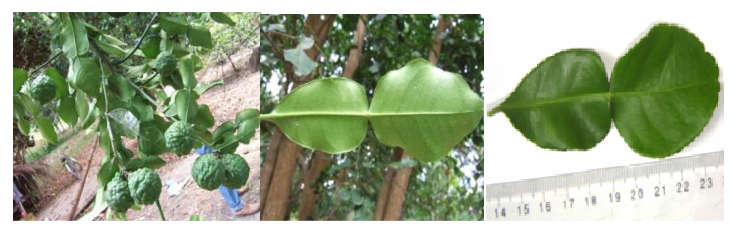

Fig. 1. Fruits, leaves of Kaffir lime (Citrus hystrix)

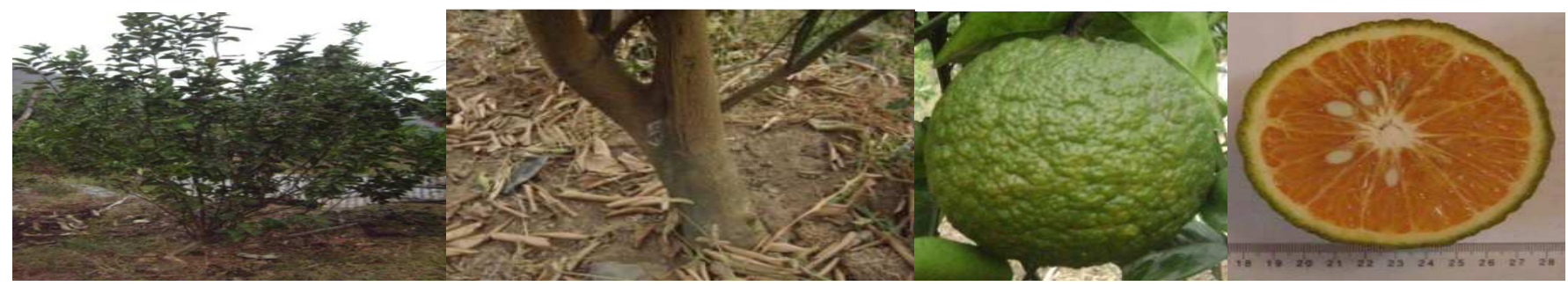

Fig. 2. (Left to right) Performance, grafted union and fruit of Sanh orange budded on Kaffir lime Vietnam (2013)
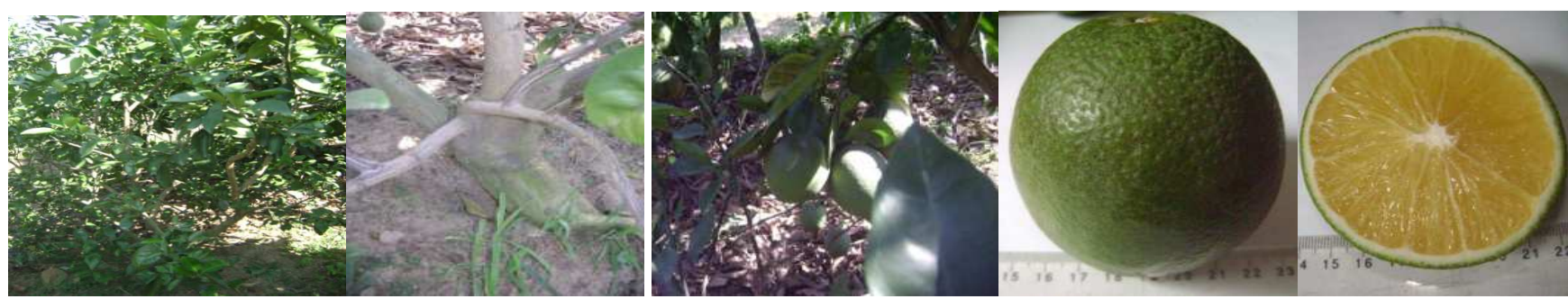

Fig. 3. (From left to right) Performance, grafted union and fruit of seedless Mat orange grafted on Kaffir lime, at Mekong Delta, Vietnam (2013)

Likewise, data in table 7 also showed that rind thickness of fruit were range from $1.43 \mathrm{~mm}$ of Duong mandarin to $18.03 \mathrm{~mm}$ of $\mathrm{Da}$ xanh pumelo. For determining the good compatibility between scion and rootstock, the visual and sensorial evaluations of color, flavor and aroma of fruit juice were also undertaken and presented in table 8, the trees of Sanh orage budded on Kaffir lime produced fruits with better color development, better flavor and aroma of fruit juice. So, the most prominent quality of fruits were from trees of Sanh orage budded on Kaffir lime and followed by that of seedless Mat orange on Kaffir lime, which produced highest number of harvested fruits with seedy fruit, lower total soluble solids. As compared to the typical fruit quality, Da xanh pumelo budded on Kaffir lime yielded seedy fruits with the loose juice sacs, bitter flavor fruit juice. In addition, fruits from tested other combinations of scions and rootstocks were inferior color, flavor and aroma of fruit juice, differed from the specific characteristics. 
TABLE VIII

FRUIT QUALITY AS COMPARED TO SPECIFIC CHARACTERISTICS

\begin{tabular}{|l|l|}
\hline \multicolumn{1}{|c|}{ Scion/stock } & \multicolumn{1}{c|}{$\begin{array}{c}\text { Compared to specific characteristics } \\
\text { of variety }\end{array}$} \\
\hline $\begin{array}{l}\text { Seedless Mat } \\
\text { orange/Kaffir lime }\end{array}$ & -Seedy fruit, lower total soluble solids \\
\hline $\begin{array}{l}\text { Sanh orange/Kaffir } \\
\text { lime }\end{array}$ & $\begin{array}{l}\text {-Lager fruit size, higher total soluble } \\
\text { solids, better color development of fruit } \\
\text { juice, better flavor and aroma of fruit } \\
\text { juice }\end{array}$ \\
\hline $\begin{array}{l}\text { Da xanh } \\
\text { pumelo/Kaffir lime }\end{array}$ & $\begin{array}{l}\text {-Thinner fruit rind, seedy fruit, lower } \\
\text { brix value, looser juice sacs, bitter fruit } \\
\text { juice and loosen juice sacs }\end{array}$ \\
\hline $\begin{array}{l}\text { Duong } \\
\text { mandarin/Kaffir lime }\end{array}$ & -Lower total soluble solids \\
\hline $\begin{array}{l}\text { Seedless Mat } \\
\text { orange/Carrizo }\end{array}$ & -Lower total soluble solids \\
\hline $\begin{array}{l}\text { Sanh orange/Carrizo } \\
\text { solids, thicker fruit rind, higher number } \\
\text { of seeds }\end{array}$ \\
\hline $\begin{array}{l}\text { Da xanh } \\
\text { pumelo/Carrizo }\end{array}$ & $\begin{array}{l}\text {-Smaller fruit size, larger rind thickness, } \\
\text { lower total soluble solids, higher } \\
\text { number of seeds, loosen juice saces, } \\
\text { bitter flavor of fruit juice }\end{array}$ \\
\hline $\begin{array}{l}\text { Duong } \\
\text { mandarin/Carrizo }\end{array}$ & - Lower total soluble solids \\
\hline
\end{tabular}

The results of the current investigation agreed with earlier reports of Tazima et al. (2013) on affecting of rootstock on yield, who found that Okitsu Satsuma grafted on Swingle citrumelo gave heavier yield of fruit as compared to that on Rangpur lime and Volkamer [10]. Likewise, Pham Thi Huong (2006) found that growth and yield of Duong Canh mandarin was affected by rootstock [8].

On the other hand, those were also in lines with the findings mentioned by Ercan et al. (2013), those investigations were growth and development of the grafted trees, fruit yield, fruit weight and total soluble solid of orange cv. Rhode Red Valencia and Valencia Late mandarin depended on the different rootstock used for grafting [9].

Likewise, Benjamin et al. (2013) proved that rootstocks affected sensory quality, total soluble solids and aroma volatiles compositions of 'Or' and 'Odem' mandarins; especially, fruit flavor depended on specific rootstock/ scion interactions [1].

So, the results primarily demonstrated that Kaffir lime rootstock was a supperior to Carrizo citrange, better for current commercial variety scions of Da xanh pumelo, Sanh orange, seedless Mat orange, Duong mandarin. Out of the experimental combinations of Kaffir lime rootstock, it was found that Sanh orange budded on Kaffir lime was elite combination when based on starting to produce fruits after planting, vegetaive traits of tree height, canopy volume, trunk diameter, scion and stock ratio; on number of harvested fruits; and on the fruit quality of larger fruit size, higher total soluble solids, better color development of fruit juice, excellent flavor and aroma in comparison to the typical variety characteristics.

\section{CONCLUSIONS}

Therefore, it could be safely concluded that in $3^{\text {rd }}$ and $4^{\text {th }}$ year after planting under field trial, the trees of Sanh orange (C. nobilis Lour.) budded on Kaffir lime (Citrus hystrix) were outstanding of the tested combinations, based on precocity, on producing high number of fruits (16.67 fruits per tree) with good fruit quality of larger fruit size (334.6 g and $11.16 \mathrm{~cm}$, fruit weight and diameter, respectively), higher total soluble solids (12.5 brix), better orange-yellow juice color development, and excellent flavor and aroma of juice, as compared to the typical characteristics; and this was followed by trees of seedless Mat orange budded on Kaffir lime, that produced the highest number of fruits (47.33 fruits per tree) with little inferior fruit quality of seedy fruit (1-3 seeds per fruit), lower total soluble solids ( $7.33 \mathrm{brix}$ ), and no good flavor and aroma, as somewhat differed from the typical fruit traits.

\section{ACKNOWLEDGMENT}

The research work reported in this paper was supported by the "Selection of citrus rootstocks for tolerance to extremely acid sulfate soil, drought conditions at Mekong Delta Vietnam 2008-2013" research project that was funded by Ministry of Agriculture and Rural Development (MARD), Vietnam. Special thanks to Staffs of Division of Agriculture and Rural Development Tri Ton, An Giang, Vietnam, and farmers for the valuable collaboration and support for carrying out the research.

\section{REFERENCES}

[1] G. Benjamin, Z. Tietel, and R. Porat, Effects of rootstock/scion combinations on the flavor of citrus fruit, J. Agric. Food Chem, 2013, vol. 61(47), pp: 11286-94.

[2] Le Thi Khoe, Nguyen Van Tho and Nguyen Minh Chau. Early selecting, screening the tolerance of the native citrus genotypes to drought under greenhouse conditions at Mekong Delta. Vietnam Journal of Agriculture and Rural Development. pp. 145-152. ISSN 1859-4581, 2013.

[3] Le Thi Khoe, Tran Van Mi, Nguyen Van Tho, Do Hong Tuan, Nguyen Ngoc Anh Thu and Vo Huu Thoai. Drought resistance of the local citrus genotypes under the field conditions at Tinh Bien-An Giang Vietnam. Journal of Vietnam Agricultural Science and Technology. 6(36): 14-17. ISSN 1859-1558,2012.

[4] M. Bauer, W.S. Castle, B.J. Boman and T.A. Obreza, "Economic longevity if citrus trees on Swingle citrumelo rootstock and their suitability for soils of the Indian River region", Proc. Fla. State Hort. Soc. 2005, vol 118, pp: 24-27.

[5] M.A. Bassal, "Growth yield and fruit quality of 'Marisol' clementine grown on four rootstocks in Egypt" Scientia Horticulturae 2009, vol. 119(2), pp: 132-137.

[6] M.N. Westwood, 1993, Temperate-zone pomology, physiology and culture. Timber press, Portland, Oregon, USA.

[7] P. Legua, R. Bellver, J. Forner, M.A. Forner-Giner, "Plant growth. yield and fruit quality of 'Lane Late' navel orange on four citrus rootstocks". Spanish Journal of Agricultural Research, 2011, vol. 9(1), pp: 271-279.

[8] Pham Thi Huong, "Effect of sexually and vegetative propagated rootstock of Duong Canh mandarin grown in Gia Lam, Hanoi, Vietnam J. Agr. Rural Devel., 2006, vol 4(6), pp: 18-21.

[9] Y. Ercan, H.D. Turan, and K. Mustafa, "Growth, yield, and fruit quality of 'Rhode Red Valencia' and 'Valencia Late' sweet oranges grown on three rootstocks in eastern Mediterranean", Chilean J. Agric. Res., 2013, vol 73(2), pp: 142-146.

[10] Z.H. Tazima, C.S.V.J. Neves, I.F.U. Yada, and R.P. Leite Junior, "Performance of 'Okitsu' Satsuma Mandarin on nine rootstocks. Sci. Agric, 2013, vol. 70(6), pp: 422-427. 